\title{
Assessment of instream structures for habitat improvement for two critically endangered fish species
}

\author{
I. Boavida $\cdot$ J. M. Santos $\cdot$ R. V. Cortes $\cdot$ \\ A. N. Pinheiro $\cdot$ M. T. Ferreira
}

Received: 18 February 2010/Accepted: 14 August 2010/Published online: 27 August 2010

(C) Springer Science+Business Media B.V. 2010

\begin{abstract}
The number of fish habitat improvement schemes has greatly increased in response to the widespread degradation of aquatic ecosystems. However, many of these enhancement projects often fail to create expected habitat conditions, because they are rarely planned and executed with inputs from the species' habitat requirements throughout their life histories, and it is frequently assumed that the implementation of a specific instream structure for habitat improvement will always benefit all species present. Using a 2D hydraulic model, the present study evaluates the potential habitat improvement for two critically endangered fish species - the Southwestern arched-mouth nase Iberochondrostoma almacai and the Arade chub Squalius aradensisresulting from simulating the introduction of different instream structures (islands, lateral bays, and deflectors) in a modified Mediterranean river reach. The
\end{abstract}

Handling Editor: Thomas Mehner.

I. Boavida $(\bowtie) \cdot$ A. N. Pinheiro

Instituto Superior Técnico, Technical University

of Lisbon, Lisbon, Portugal

e-mail: isabelboavida@ist.utl.pt

J. M. Santos - M. T. Ferreira

Forest Research Centre, Technical University

of Lisbon, Lisbon, Portugal

R. V. Cortes

Forestry Department, University of Trás-os-Montes

and Alto Douro, Vila Real, Portugal introduction of islands in the river channel was found to be the best improvement measure for YOY and juvenile nase and chub, as shown by increases in the mean annual Weighted Usable Area (WUA) of more than 100 and 50\%, respectively, compared to the present conditions. On the other hand, the simulation with current deflectors proved to be the worst scenario, particularly for nase, with mean annual WUA decreasing by $3.6,17.8$ and $22.7 \%$ for YOY, juveniles and adults, respectively. The findings of this study point to the need to account for different species life-history stages when modelling the implementation of instream structures for habitat improvement and also provide a sound basis for future conservationrelated studies conducted in Mediterranean rivers that harbour other threatened "sister" species.

Keywords Instream structures ·

Habitat improvement · Fish · Life history ·

River2D · WUA

\section{Introduction}

Rivers are the type of ecosystem that is most affected by humans, and the species they support are among the most imperilled worldwide (Jenkins 2003; Nilsson et al. 2007). This means there is a need for redoubled efforts if we are to reverse declining trends (Dudgeon et al. 2006). Instream habitat enhancement projects have therefore become a priority for water 
authorities in many countries (Bernhardt and Palmer 2007; Jansson et al. 2007; Nilsson et al. 2007) and are expected to multiply over the next few years due to the implementation of the Water Framework Directive (EC 2000). Given both the high costs involved and socio-administrative expectations, habitat improvement projects must successfully apply science-based tools. However, such projects are often undertaken on a trial basis with erroneous practices and with no prior analysis of their potential effectiveness (Downs and Kondolf 2002), frequently with the assumption that implementation of a given habitat improvement measure (e.g. current deflectors) will always benefit the instream habitat of the whole range of species present. At the same time, the economic importance of salmonid and other game species means that most habitat enhancement research has been devoted to them, whereas studies on nonrheophilic coarse species are scarce and have often been neglected (e.g. Langler and Smith 2001). This is highly unfortunate, since these species are an important biological component of fish assemblages and some of them are critically endangered due to humaninduced habitat modification. In addition, different species and life histories may require distinct physical habitats (Schlosser 1995). It is clearly necessary to adopt systematic approaches that greatly increase the chances of habitat improvement success (Palmer et al. 2005).

Advances in the ecological modelling of rivers have recently provided powerful tools for representing complex interactions between fish populations and their habitat. Increasingly, habitat creation or improvement is used to mitigate loss of fish habitat (Pasternack et al. 2004). Such compensation plans involve modelling potential alternative enhancement scenarios intended to provide stream features that allow fish to meet their needs for migration, reproduction and shelter. Habitat simulations resulting from the placement of different instream structures may therefore be used to assess whether a concrete action will significantly enhance fish habitat, and whether it will be worth executing it (Smith et al. 2002). Studies evaluating different instream habitat enhancement options are often performed using one-dimensional models that only describe spatial variations along one direction. The fact is that twodimensional hydrodynamic models offer significant improvements over 1D modelling, since they more accurately represent spatial variations and combinations of flow patterns that influence fish population (Crowder and Diplas 2000).

The goal of this study was to use 2D hydraulic simulations to evaluate potential habitat improvement for two critically endangered cyprinid species-the South-western arched-mouth nase Iberochondrostoma almacai (hereafter nase) and the Arade chub Squalius aradensis (hereafter chub)—a limnophilic and a eurytopic species, respectively. The habitat improvement entails implementing distinct instream structures-(i) placing three islands in the middle of the river channel; (ii) introducing two lateral bays on opposite banks; and (iii) introducing four alternate current deflectors-in a modified river reach of a Mediterranean river. Though the use of such instream structures has been considered in many habitat improvement projects (e.g. Vehanen et al. 2003; Garcia de Jalón and Gortázar 2007), no previous analysis of their potential effectiveness for fish habitat has been carried out in non-salmonid rivers. This information can prove useful elsewhere, namely in other Mediterranean-type rivers, where the implementation of instream structures and compensatory measures as a means of recovering other threatened fish populations has been questioned.

\section{Methods}

Study area

The study was conducted in the Odelouca River-the largest tributary (total length $=92 \mathrm{~km}$ ) of the Arade basin $\left(987 \mathrm{~km}^{2}\right)$, southwest Portugal (Fig. 1). It is a medium-sized low-gradient river, running through schistose areas that are characteristic of southern Portugal. River topography varies from narrow, steep-sided valley walls to restricted meander valleys and small floodplains along the lower reaches. The climate is typically Mediterranean, with annual rainfall following a predictable seasonal pattern (wet season from October to March, dry season from June to August), resulting in a relatively slowrunning river that is subject to high discharge peaks during the winter and leaving temporarily unconnected pools in the riverbed during summer. The upper and middle areas of the catchment are of high conservation value, with well-developed riparian 
galleries dominated by Alnus glutinosa L., Salix salviifolia Brot. ssp. australis Franco and Fraxinus angustifolia Vahl and are free of major human impacts such as urban pollution, impoundment and angling. Land use on the lower reaches is mainly agricultural. Extensive citrus groves now occupy the lower catchment, replacing the natural Mediterranean scrubland and cork-oak woodland vegetation (Quercus suber L.). These activities changed the hydromorphology of the river by decreasing habitat heterogeneity through the destruction of the riparian corridor and bank reinforcement. Nase and chub used to be the dominant species in the whole catchment (Pires et al. 2004) but are now almost absent from the lower part as a result of human-induced habitat modification. Other fish species presently recorded in the study reach include the European eel (Anguilla anguilla L.) and the Iberian loach (Cobitis paludica de Buen).

Sampling methods

A two-dimensional approach was chosen for habitat simulation modelling, as these models have been shown to give a better flow representation than onedimensional models, and are also able to simulate complex flow patterns, such as recirculation and transverse water surface slopes (Ghanem et al. 1996). Specifically, we used the River2D model (Steffler 2000) - a 2D hydrodynamic and fish habitat model. This finite element model simulates hydraulic conditions from topographic data input, and uses the habitat suitability index curves containing known biological preference data, to calculate the potential habitat for specific species life-history stages by the Weighted Usable Area (WUA). The accuracy of 2D models has been assessed in different studies (Ghanem et al. 1996; Crowder and Diplas 2000; Lacey and Millar 2004; Pasternack et al. 2004) with promising results.

A 250-m-long reach that was representative of the river segment was modelled. The catchment area above the study site is $466 \mathrm{~km}^{2}$, with a mean annual flow of $4.05 \mathrm{~m}^{3} \mathrm{~s}^{-1}$. On this reach, cross-sections range from 7 to $30 \mathrm{~m}$ wide, with a $0.0035 \mathrm{~mm}^{-1}$ slope. The riverbed topography was surveyed with a combination of a Nikon DTM310 total station and a Global Positioning System (GPS) (Ashtechy, model Pro Mark2). Additionally, bed elevation and substratum composition, which was measured using a modified Wentworth scale (Bovee 1986) [(1) organic cover; (2) silt (1-2 mm); (3) sand (2-5 mm); (4) gravel (5-25 mm); (5) pebble (25-50 mm); (6) cobble (50-150 mm); (7) boulder (>150 mm); and (8) bedrock] were collected. Altogether, 4,129 spots were surveyed. To calibrate the model, a series of points were located along cross-sections where significant alterations in depth, water velocity, substratum composition and slope were noted. Depths were measured with a ruler. Water velocities were measured with a water flow probe (model FP101, Global Water Instrumentation, USA) at $60 \%$ of the distance from the water surface to the riverbed (Bovee and Milhous 1978). The boundary conditions were established by
Fig. 1 Map of the study area, showing the location of the Odelouca River and the studied reach

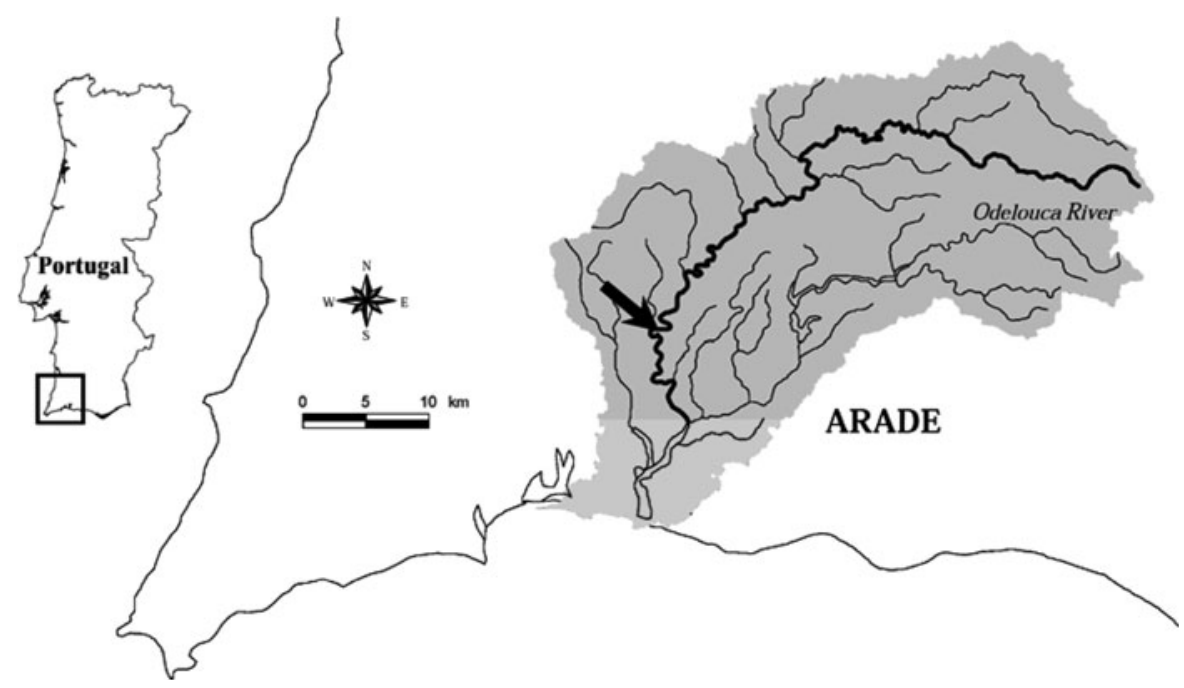


measuring discharge and water surface elevations at the lower cross-section. Discharge was assumed to be constant, as no tributaries joined the study reach. Different bed roughness coefficients (Manning's n) were estimated in accordance with observations of bed material and bedform size. The final values were obtained by calibrating the model results to the measured water surface elevations and the water velocity profile in different cross-sections.

Habitat suitability curves (HSC) for depth, velocity and substratum were previously developed for specific fish-size classes, according to differences in length and age structure (Santos and Ferreira 2008): $<5,5-7$ and $>7 \mathrm{~cm}$ for nase and $<4,4-6$ and $>6 \mathrm{~cm}$ for chub, roughly corresponding to the fish lifehistory stages of YOY $(0+)$, juveniles $(1+)$ and adults $(>1+)$, respectively. Sampling took place at undisturbed or minimally disturbed sites in the Odelouca catchment-an essential requisite when building HSC, in order to reflect the optimal habitat of species and not an externally imposed displacement towards sub-optimal situations (Gorman and Karr 1978). Fish sampling was performed during the flowing season-late May to early June-when there is full connectivity among habitats and fishes are therefore not restricted to isolated pools. A 250-mlong study section on each site was electrofished to encompass repeating habitat types (riffles, runs and pools). Sampling was undertaken during daylight hours using pulsed DC electrofishing (SAREL model WFC7-HV, Electracatch International, Wolverhampton, UK), with low voltage $(250 \mathrm{~V})$ and a $30-\mathrm{cm}-$ diameter anode to reduce the effect of positive galvanotaxis. The sampling crew-one person operating the shocker and the other using a dip net to catch stunned fish-moved upstream in a zigzag pattern to ensure full coverage of the habitats. To avoid displacements of individuals from their original positions, a modified point electrofishing procedure was employed (Copp 1989). Sampling points were approached discreetly, and the activated anode was swiftly immersed in the water for $5 \mathrm{~s}$ at equidistant locations (every $0.5 \mathrm{~m}$ ). Upon sighting a fish or a shoal of fishes, a numbered location marker was anchored to the stream bed for subsequent microhabitat use measurements. Fish were immediately collected by means of a separate dip net held by another operator, quickly measured for total length (TL), and then placed in buckets with portable ELITE aerators to avoid continuous shocking and repeated counting, before being returned alive to the river. Following fish sampling, depth of water column $(\mathrm{cm})$, mean water velocity $(\mathrm{cm} / \mathrm{s})$ and dominant substratum composition were measured in $0.8 \times 0.8 \mathrm{~m}$ quadrats directly below the fish. These have been considered the three most important variables determining fish diversity and distribution (Gorman and Karr 1978). Depth was measured with a meter rule to the nearest centimetre. Water velocities were measured with a water flow probe (model FP101, Global Water Instrumentation, Inc., USA). For depths of less than $0.8 \mathrm{~m}$, mean water velocity was measured at $60 \%$ of the distance from the surface to the substratum; otherwise, water velocity was considered to be the mean of measurements taken at 20 and $80 \%$ of total depth (Bovee and Milhous 1978). Substratum was measured according to the modified Wentworth scale (Bovee 1986). Microhabitat availability measurements were made using the same variables by quantifying randomly selected points along 15-25 equidistant transects perpendicular to the flow at each sampling site. In order to develop HSC for target fishsize classes, microhabitat variables (depth, water velocity and substratum composition) were divided into classes, and histograms of frequencies of use and availability were built (Vismara et al. 2001). The suitability index was calculated as the ratio between proportional use and availability and then normalized, dividing by the maximum suitability value so that the minimum value was 0 and the maximum was 1 .

The WUA-i.e. the surface $\left(\mathrm{m}^{2}\right)$ that can be potentially used by a given fish life-history stagewas then computed as the product of depth, velocity and substratum suitability indexes. This was used to evaluate the performance of three potential habitat enhancement measures, relative to the present stream reach conditions: (i) introducing three islands in the mid-section of the channel; (ii) introducing two lateral bays on opposite banks; and (iii) introducing four alternate current deflectors (Fig. 2). The number of each type of instream structure was chosen to approximately match the wetted areas for each flow discharge (Table 1). These scenarios were designed in R2D_Bed-the bed topography file editor of the River2D model.

These particular scenarios were chosen because they were found to improve the stream bed complexity (Roni et al. 2005) and therefore potentially 

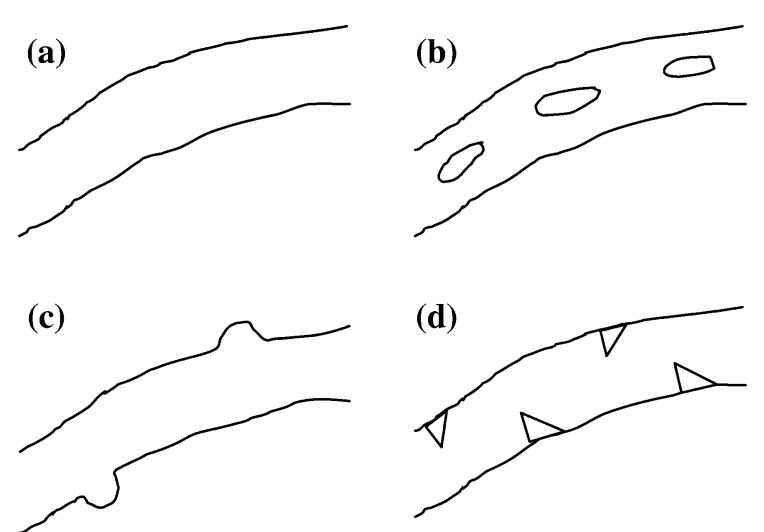

Fig. 2 Sketch of the study reach (horizontal plan) with, a the present condition; and considering the placement of the different instream structures: $\mathbf{b}$ three islands in the middle of the channel; c two lateral bays on opposite sides; and $\mathbf{d}$ four alternate triangular deflectors

improve the fish habitat for all the life-history stages. Each new riverbed topography was then introduced in the River2D model, and simulations were carried out for river discharges from 0.1 to $8.0 \mathrm{~m}^{3} \mathrm{~s}^{-1}$, to ensure that the models represented common flow discharges. By comparing the WUA of the present condition with the WUA that had been obtained when considering the introduction of the different structures in the river reach, the effectiveness of each potential improvement measure can be assessed for every flow discharge:

$\mathrm{WUA}_{\text {improvement }}=\left(\mathrm{WUA}_{\mathrm{Ii}}-\mathrm{WUA}_{\mathrm{Pc}}\right) / \mathrm{WUA}_{\mathrm{Pc}}$

where $\mathrm{WUA}_{\mathrm{Ii}}$ is the Weighted Usable Area obtained for each of the tested improvement scenarios, and WUA $_{P c}$ is the Weighted Usable Area for the present stream reach condition. To account for differences in depth distribution between the present condition and the simulated improvement scenarios across different flow discharges, the relative abundance of predefined depth classes $(<0.2 ; \quad 0.2-0.4 ; \quad 0.4-0.6 ; \quad 0.6-0.8$; $0.8-1.0 ;>1.0 \mathrm{~m}$ ) of all the surveyed locations was analysed, and the Shannon-Wiener diversity $\left(\mathrm{H}^{\prime}\right)$ index was computed for each case as diversity of depth.

Finally, to analyse the timing and magnitude of habitat (WUA) variations on a temporal scale, continuous under threshold curves (CUT) (Capra et al. 1995) were developed for each species, considering the present condition and the different

Table 1 Instream percentage cover of depth classes (m) obtained for the present condition and for each of the three simulated habitat improvement scenarios: placement of three islands in the middle of the channel, introduction of two lateral bays on opposite banks and introduction of four current deflectors, across different flow discharges

\begin{tabular}{|c|c|c|c|c|c|c|c|c|c|c|}
\hline \multirow[t]{2}{*}{$\mathrm{Q}\left(\mathrm{m}^{3} \mathrm{~s}^{-1}\right)$} & \multirow{2}{*}{$\begin{array}{l}\text { Shoreline } \\
\text { length (m) }\end{array}$} & \multirow{2}{*}{$\begin{array}{l}\text { Wetted } \\
\text { area }\left(\mathrm{m}^{2}\right)\end{array}$} & \multirow[t]{2}{*}{ Scenario } & \multicolumn{6}{|c|}{ Depth (m) } & \multirow[t]{2}{*}{$\mathrm{H}^{\prime}$} \\
\hline & & & & $<0.2$ & $0.2-0.4$ & $0.4-0.6$ & $0.6-0.8$ & $0.8-1.0$ & $>1.0$ & \\
\hline \multirow[t]{4}{*}{1} & 534 & 4,391 & Present conditions & 63.12 & 28.65 & 7.04 & 1.19 & 0.00 & 0.00 & 0.89 \\
\hline & 647 & 5,356 & Islands & 50.21 & 36.68 & 10.90 & 2.21 & 0.00 & 0.00 & 1.04 \\
\hline & 568 & 4,798 & Bays & 62.18 & 30.27 & 6.46 & 1.09 & 0.00 & 0.00 & 0.88 \\
\hline & 570 & 4,382 & Deflectors & 59.16 & 33.32 & 7.14 & 0.38 & 0.00 & 0.00 & 0.89 \\
\hline \multirow[t]{4}{*}{3} & 571 & 5,598 & Present conditions & 33.89 & 51.61 & 11.59 & 2.91 & 0.00 & 0.00 & 1.06 \\
\hline & 567 & 6,539 & Islands & 36.30 & 35.50 & 22.09 & 6.04 & 0.07 & 0.00 & 1.24 \\
\hline & 618 & 5,987 & Bays & 31.80 & 54.50 & 10.97 & 2.73 & 0.00 & 0.00 & 1.04 \\
\hline & 592 & 5,759 & Deflectors & 35.46 & 49.23 & 13.25 & 2.06 & 0.00 & 0.00 & 1.06 \\
\hline \multirow[t]{4}{*}{5} & 547 & 6,633 & Present conditions & 33.18 & 38.88 & 24.28 & 3.63 & 0.03 & 0.00 & 1.20 \\
\hline & 566 & 7,032 & Islands & 24.65 & 34.17 & 30.31 & 9.59 & 1.28 & 0.00 & 1.36 \\
\hline & 518 & 6,850 & Bays & 29.52 & 40.73 & 26.05 & 3.67 & 0.03 & 0.00 & 1.20 \\
\hline & 590 & 6,808 & Deflectors & 34.31 & 33.99 & 28.19 & 3.51 & 0.00 & 0.00 & 1.21 \\
\hline \multirow[t]{4}{*}{7} & 576 & 7,129 & Present conditions & 30.65 & 26.80 & 36.46 & 5.49 & 0.59 & 0.00 & 1.27 \\
\hline & 580 & 7,496 & Islands & 18.83 & 33.50 & 29.48 & 15.32 & 2.85 & 0.02 & 1.43 \\
\hline & 518 & 7,316 & Bays & 26.98 & 29.29 & 37.73 & 5.43 & 0.58 & 0.00 & 1.27 \\
\hline & 576 & 7,216 & Deflectors & 29.55 & 27.28 & 36.22 & 6.82 & 0.13 & 0.00 & 1.27 \\
\hline
\end{tabular}

The Shannon index $\left(\mathrm{H}^{\prime}\right)$ of diversity is also shown 


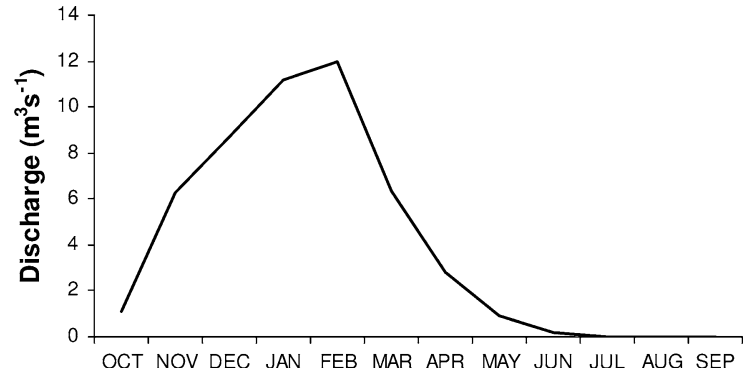

Fig. 3 Natural flow regime calculated from daily flow data from 1961-2001 and recorded at the Monte dos Pachecos gauging station, located $5 \mathrm{~km}$ upstream from the studied reach

habitat improvement scenarios, in order to choose from all the potential instream structures the one that best benefits a specific life-history stage. The curves evaluate the duration and frequency of continuous events with a habitat below a specific threshold as a proportion of the entire study period (Capra et al. 1995). First of all, hydrologic time series (Cole et al. 2003) were computed using daily flow data from a nearby gauging station (Monte dos Pachecos) (Fig. 3). The station is only $5 \mathrm{~km}$ upstream from the study reach, and daily flow data for a period of 40 years (1961-2001) were considered to be representative of the local conditions. Nevertheless, in order to more feasibly represent the daily flow regime in the study reach, the daily flow data for the latter were determined by multiplying the available daily flow data for the gauging station by an adjusting factor corresponding to the quotient between the study reach catchment area and the gauging station catchment area. The natural flow regime for the year period was then calculated considering the median daily flow. To calculate the CUT curves, the WUA versus discharge curves were integrated with the daily hydrologic time series to obtain the habitat time series. Finally, the CUT curves were created considering the duration, in days, for which the WUA was lower than a given threshold. These periods, during which WUA $<\mathrm{WUA}_{\text {threshold, }}$, were sorted from the longest to the shortest period. Points were then plotted with coordinates equal to the number of days of the period as the $Y$-axis, and the cumulative percentage of this number of days in relation to the total number of days of the studied time as the $X$-axis. Finally, a curve was fitted to the points to facilitate graph production. Further details of the development of CUT curves are given in Capra et al. (1995). The
Fig. 4 Variation in WUA for the different species life-history stages at different flow discharges: under the present condition a nase, $\mathbf{b}$ chub; when simulating the placement of three islands in the middle of the channel $\mathbf{c}$ nase, $\mathbf{d}$ chub; when simulating the placement of two lateral bays on opposite banks e nase, f chub; and when simulating the placement of four alternate current deflectors $\mathbf{g}$ nase, $\mathbf{h}$ chub

threshold considered in the present study was $80 \%$ of the maximum WUA that occurred at the control situation, and the studied time was 365 days.

\section{Results}

Discharge measured at the study reach was $2.05 \mathrm{~m}^{3} \mathrm{~s}^{-1}$. Figure $4 \mathrm{a}$ and $\mathrm{b}$ shows variations in WUA according to flow discharge in the present condition, for the different life-history stages of nase and chub, respectively. Overall, chub presented higher WUA values (range: $239-2,032 \mathrm{~m}^{2}$ ) than nase (range: 40-232 $\mathrm{m}^{2}$ ). Maximum habitat area for nase occurred at discharges of around $1 \mathrm{~m}^{3} \mathrm{~s}^{-1}$ for all life stages. Ontogenetic differences were found for chub, however. Accordingly, maximum adult habitat area occurred at approximately $6 \mathrm{~m}^{3} \mathrm{~s}^{-1}$, whereas for earlier stages-i.e. YOY and juveniles-it was reached at 0.5 and $2 \mathrm{~m}^{3} \mathrm{~s}^{-1}$, respectively.

Simulation with three islands in the middle of the channel

Placing islands in the middle of the channel produced a habitat improvement for all nase life-history stages, across the whole range of simulated flows (Fig. 4c). Habitat gains were particularly evident for YOY, whose improvement was greater than $100 \%$ within the flow range $0.5-6 \mathrm{~m}^{3} \mathrm{~s}^{-1}$, with a maximum at $3.5 \mathrm{~m}^{3} \mathrm{~s}^{-1}$. Adult habitat improvement was less than for YOY and juveniles for flows of less than $3 \mathrm{~m}^{3} \mathrm{~s}^{-1}$, attaining a maximum at $4.5 \mathrm{~m}^{3} \mathrm{~s}^{-1}$. This scenario was also beneficial for chub habitat, inasmuch as improvements were found for all life stages (Fig. 4d). Habitat improvement for YOY was maximal at $3 \mathrm{~m}^{3} \mathrm{~s}^{-1}$, decreasing for higher flows. In contrast, improvement increased with higher flows in the case of juvenile individuals, attaining a maximum at approximately $6.0 \mathrm{~m}^{3} \mathrm{~s}^{-1}$. 

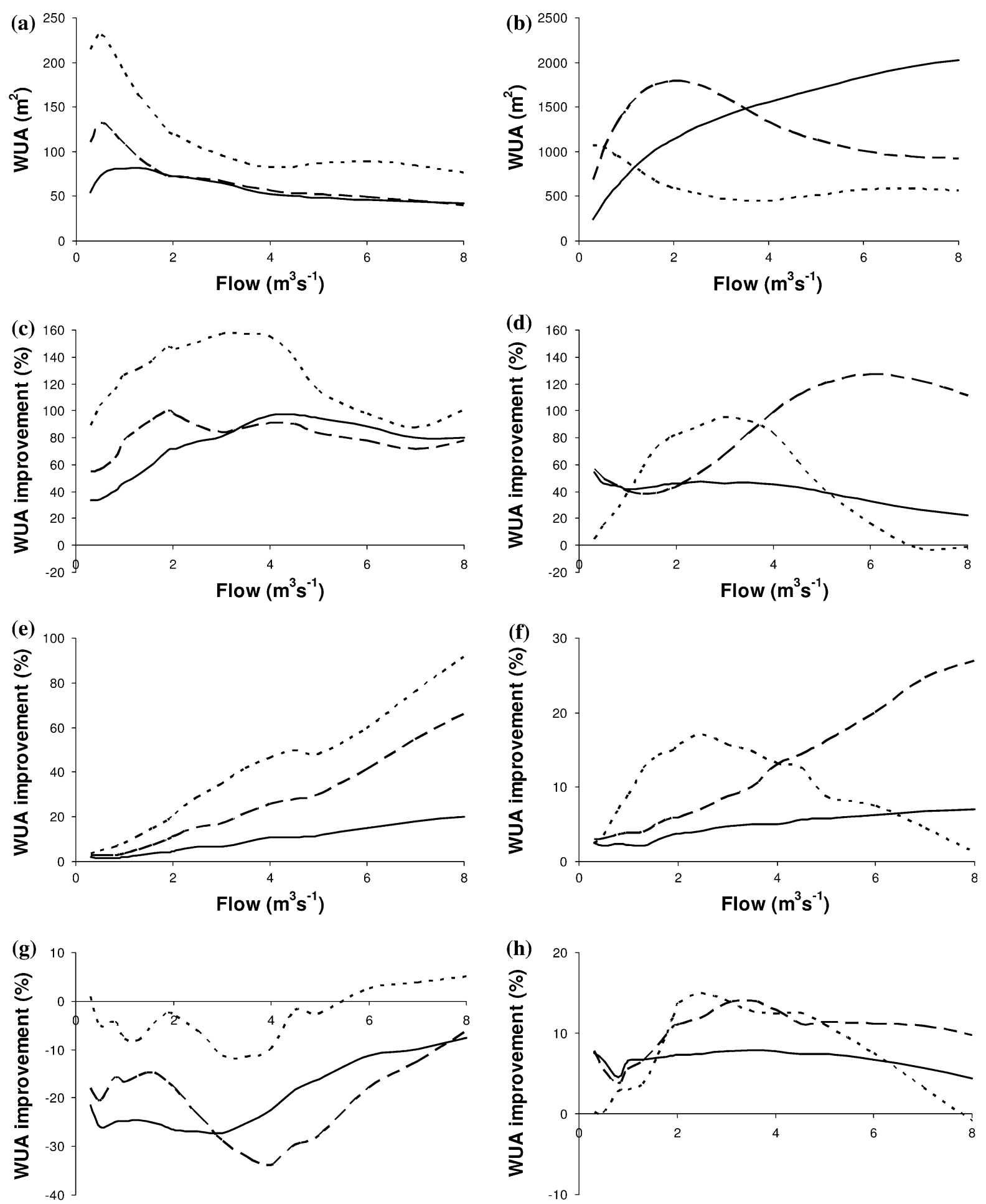

Flow $\left(\mathrm{m}^{3} \mathrm{~s}^{-1}\right)$

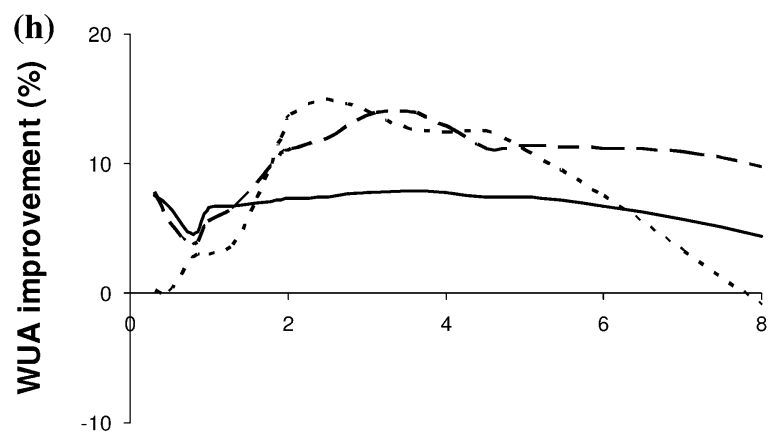

Flow $\left(\mathrm{m}^{3} \mathrm{~s}^{-1}\right)$

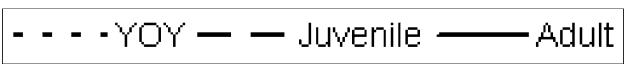


The placement of islands was found to be the instream structure that most favoured the occurrence of higher depths (i.e. $>0.4 \mathrm{~m}$ ), thereby increasing depth diversity (Table 1).

Simulation with two lateral bays on opposite banks

The second improvement measure simulated in this study was the placement of two lateral bays on opposite banks.

Placing these instream structures yielded an improvement in habitat compared to the present condition, although to a lesser extent than the islands, for both species' life stages. All nase life stages behaved in similar ways, with habitat improvement increasing continuously with flow discharge for the range of simulated flows, albeit this was more evident in the case of YOY (Fig. 4e). In the case of chub, improvement was greater for YOY at low flows (c. $17 \%$-i.e. $2-3 \mathrm{~m}^{3} \mathrm{~s}^{-1}$-followed by a habitat decrease with increasing discharges. For advanced stages, habitat gains were greater at higher discharges $-7-8 \mathrm{~m}^{3} \mathrm{~s}^{-1}$ - particularly for juveniles, which showed a $25 \%$ improvement over the present conditions (Fig. 4f).

Simulation with four alternate current deflectors

The last improvement measure considered was the placement of four alternate current deflectors along the studied reach.

These instream structures proved to be the worst for both species, and especially for nase, due to a lack of improvement across almost the whole range of flow discharges (Fig. 4g). Accordingly, no improvement was observed for the whole range of discharges for either juveniles or adults, while for YOY only a very small improvement (about 5\%) was noted for higher discharges $\left(7-8 \mathrm{~m}^{3} \mathrm{~s}^{-1}\right)$. Unlike nase, habitat improvement was observed for chub, but it was also much smaller than that previously obtained by placing islands in the middle of the channel (Fig. 4h). Maximum YOY habitat improvement (c. 15\%) occurred at $2.5 \mathrm{~m}^{3} \mathrm{~s}^{-1}$, decreasing sharply thereafter to values of 0 at higher discharges $\left(8 \mathrm{~m}^{3} \mathrm{~s}^{-1}\right)$. Juvenile and adult curves presented a similar behaviour, except that juvenile habitat increased more between 2 and $8 \mathrm{~m}^{3} \mathrm{~s}^{-1}$ than did adult habitat.
Habitat improvement measures assessment

The continuous under threshold curves (CUT) shown on Fig. 5 consider the different habitat improvement measures. Nase displayed the best response to the placement of three islands in the middle of the channel, as reported by the shortest continuous periods under threshold relative to the other improvement measures (Fig. 5a-c). The implementation of current deflectors yielded the worst results in terms of habitat improvement for all life stages during the considered time period (Fig. 5c). Indeed, the highest continuous periods under threshold were found to occur for this improvement measure, especially for the adult nase, when the WUA was lower than the defined threshold throughout the whole period (365 days).

In the case of chub, the CUT revealed that placing islands was the best alternative for this species, as showed by the shortest continuous periods under threshold relative to the other improvement measures (Fig. 5d-f), with the exception of the juveniles, where the control situation exhibited shorter periods. CUT for adult chub revealed the same pattern for all the improvement measures, with the highest continuous period under threshold occurring for more than 140 days.

\section{Discussion}

A two-dimensional modelling approach was employed to predict the habitat improvement for endangered cyprinid species to be gained by introducing distinct instream structures-islands, lateral bays and current deflectors-in a physically modified river reach. The results of this study enabled us to identify instream structures that can best lead to improvements in the habitat of species-specific life-history stages, to the quantification of associated gains and losses, and to an assessment of whether it is worth constructing them.

Simulating the placement of different instream structures on the riverbed, across the range of flow discharges, and comparing them with habitat evaluations of the present condition yielded distinct results. Placing islands in the middle of the channel was found to be the best improvement measure for both species, in particular for YOY and juveniles. The 


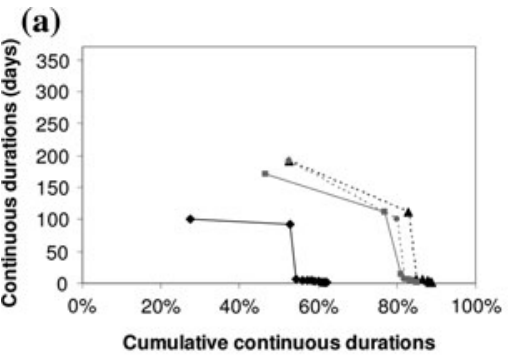

(d)

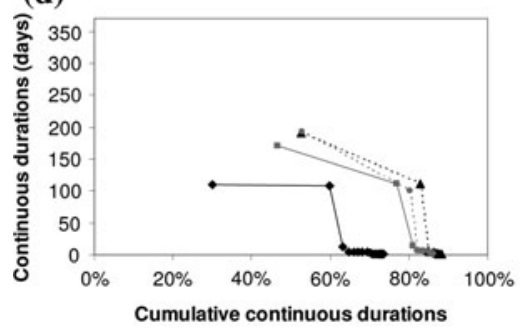

(b)

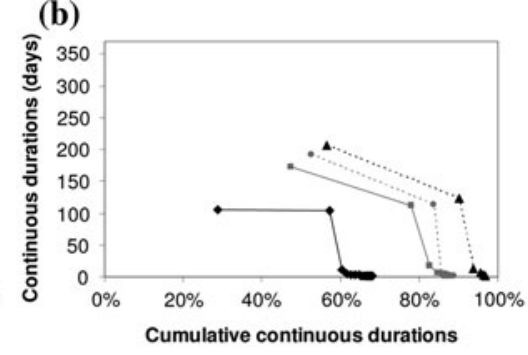

(e)

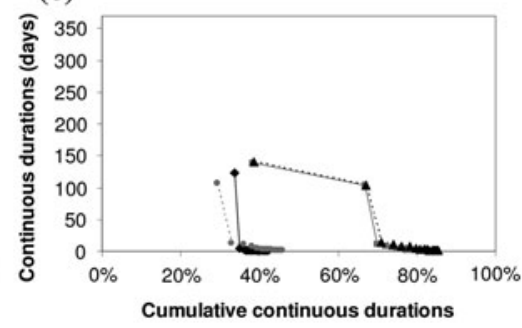

(c)

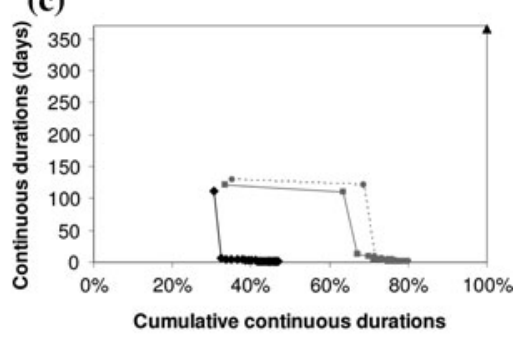

(f)

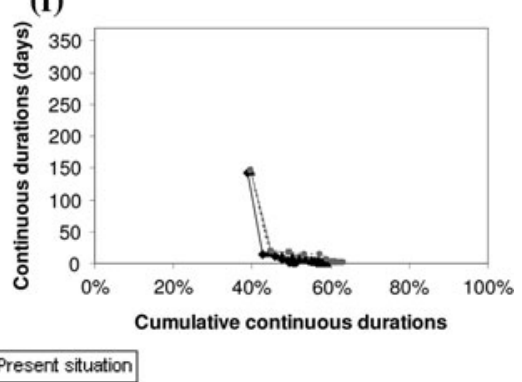

Fig. 5 Continuous under threshold curves for nase a, b and $\mathbf{c}$ and chub $\mathbf{d}, \mathbf{e}$ and $\mathbf{f}$ obtained when simulating the placement of different instream structures on the studied reach and considering a threshold of $80 \%$ of the maximum WUA that occurs in the control situation introduction of islands helps enhance the species' rearing and spawning habitat by deflecting flows and providing additional cover (Tánago and Garcia de Jálon 2007). In addition, the placement of islands in a river reach has been shown to increase diversity of depths (Cowx and Welcomme 1998). This situation was observed in the present study: of all the tested scenarios, the islands predicted the highest depth diversity and the greatest cover of high depths $(>40 \mathrm{~cm})$ along the reach under the range of simulated flows. These factors may be beneficial for both species, and for nase in particular, given that depth and cover have been recently pointed to as the key habitat variables driving this species' microhabitat use in the same river catchment (Santos and Ferreira 2008). On the other hand, the presence of shallow boulder shorelines can also represent crucial habitats for the recruitment of riverine fishes, inasmuch as they can offer important feeding areas and refuges from predators (Copp and Jurajda 1999). In the present study, such shallow and low-velocity habitats are likely to have been created in the vicinity of newly placed islands, thereby favouring the occurrence of earlier life stages such as YOY and juveniles.
The simulation results for the placement of lateral bays also revealed a habitat improvement compared to the present condition, but particularly for earlier stages of both species and albeit to a lesser extent than in the previous scenario. Very few studies have been conducted on the effect of these instream structures on lowland rivers. However, there is some evidence that they are beneficial to fish inhabiting such ecosystems (Pretty et al. 2003). The introduction of lateral bays is known to provide lentic shallow areas that are likely to produce temperatures higher than those in the main river channel (Baras and Nindaba 1999). This increase in water temperature may have direct benefits for earlier life stages, like YOY and juveniles, by increasing growth rate and energy budgets through an enhanced food assimilation rate (Langler and Smith 2001). Future studies should consider integrating water temperature into habitat simulation models in order to permit a better understanding of causal relationships and the identification of complex impact sources on the habitat use by fish. In the present study, habitat improvement was clearly evident for YOY and juvenile nase. It is possible that nase-a limnophilic species-favour the lentic nature of such habitats, particularly in the case 
of the smaller-sized individuals, given that ontogenetic differences in habitat use have been previously detected for such species, with YOY nase occupying shallower and more exposed positions than adult conspecifics (Santos and Ferreira 2008). The observed pattern of WUA improvement with increasing discharge probably reflects the compensatory phenomenon of braided Mediterranean rivers (Gasith and Resh 1999). That is with increasing discharge, losses of habitat in the major river channel are likely to be offset by gains in formerly dry inshore areas. The association of juveniles of eurytopic species with these instream habitats is also known to occur (Schiemer et al. 1991). As a eurytopic species (Santos and Ferreira 2008), chub would not restrict themselves to inshore shallow bays but would rather move alternately between the bays and the freeflowing main river channel. Future studies focused on a potential post-implementation phase and on fish movements between the bays and the main river channel would be needed to advance knowledge about the mechanisms acting on population dynamics in such systems.

The simulation of the implementation of alternate current deflectors produced the worst results in terms of WUA improvements for both species, and in particular for nase, which displayed a reduction for all life stages, relative to the present condition. Artificial instream structures, such as current deflectors, have been employed worldwide to create areas of faster flow and encourage sinuosity in flow patterns (Swales 1994). Some studies have reported a successful habitat improvement following the use of these structures (e.g. Copp and Vilizzi 2004); others did not find encouraging results after their implementation (e.g. Pretty et al. 2003; Roni et al. 2002). In a similar study, Garcia de Jalón and Gortázar (2007) did not find any significant improvement in habitat use by the Atlantic salmon Salmo salar after modelling the introduction of three current deflectors on the riverbed. These authors hypothesized that such structures work better in channelled streams, where depth is unlikely to be a limiting factor. In the present study nase responded worse than chub. This result is not surprising since, as a limnophilic species, nase would surely not be favoured by higher flow velocities created in the vicinity of such structures.

The continuous under threshold curves were particularly useful for assessing the effect of the different rehabilitation scenarios on the WUA of species life stages over the hydrologic year. Considering the number of continuous periods under threshold, introducing islands in the middle of the channel was again the improvement measure that most benefited the instream habitat of both species, and particularly younger nase. These curves may give managers and technicians a useful tool for establishing the continuous periods in which habitat is lower than a specified threshold. Specifically, in Mediterranean rivers that experience marked flow changes across an annual cycle (Gasith and Resh 1999), it would be very important to relate whether a belowthreshold habitat occurs only for short periods or is longer and persistent. Future habitat improvement studies should therefore incorporate long-term information about flood events into continuous under threshold curves.

The present study used 2D hydraulic simulations to evaluate the effect that placing different instream structures in a physically modified river reach had on the habitat of two critically endangered fish species. Of all the simulated scenarios, placing islands in the river channel was found to be the best at enhancing the habitat of both species' life-history stages, and particularly YOY and juveniles. This highlights the need to consider the use of different life-history stages when modelling habitat improvement. This is especially important from the point of view of the conservation of other endangered fish populations. The investigation of such structures should therefore not be limited to the present study; it should also serve as a starting point and a sound basis for further habitat improvement studies in Mediterranean rivers that harbour other threatened "sister" species, such as the Portuguese arched-mouth nase Iberochondrostoma lusitanicum, the calandino Squalius alburnoides and the southern Iberian chub Squalius pyrenaicus (Cabral et al. 2006). Although only one scenario for each instream structure was tested-3 islands, 2 lateral bays and 4 current deflectors-we cannot exclude the possibility that the simulation of a different number of the structures that performed less well (lateral bays and current deflectors) would have yielded a greater habitat improvement than the islands did. However, we should stress that in order to adequately assess the performance of a different number of combinations of instream structures, one would need a similar wetted area in each of the simulation scenarios for a proper 
evaluation of habitat improvement. Regardless of the best habitat instream structure, proper assessment of the outcome of the potential improvement, based on specific ecological and socio-economic attributes of the river (e.g. Woolsey et al. 2007), is needed in order to assess whether or not the proposed objectives have been met. Habitat improvement will also be dependent upon the source of available colonists. For example, Pretty et al. (2003) found a weak response of different fish species to small-scale habitat improvement schemes (current deflectors and artificial riffles), and hypothesized that one of the main reasons for the failure of such structures to improve fish habitat was the isolation of the target reach within longer sections of the degraded river. So even if they possess an a priori potential for improving a species' habitat use, the construction of small-scale schemes like those in the present study may only be effective if they are close to high-quality reaches supporting a larger number of potential colonists. In addition, the species' ability to respond positively to the chosen instream structure will also depend on whether water quality in the new scenario is sufficient to support them and on whether the species are able to disperse to and exploit the improved habitats. The failure of one or both these factors may seriously compromise the habitat improvement efforts.

Acknowledgments The authors would like to thank three anonymous reviewers whose valuable suggestions greatly contributed to the final manuscript. We would also like to thank José Lourenço for assistance with the fieldwork and Paulo Pinheiro for helping to draw the study area map. Isabel Boavida was supported by a grant (SFRH/BD/35801/2007) from FCT (Science and Technology Foundation).

\section{References}

Baras E, Nindaba J (1999) Seasonal and diel utilisation of inshore microhabitats by larvae and juveniles of Leuciscus cephalus and Leuciscus leuciscus. Environ Biol Fish 56:183-197

Bernhardt ES, Palmer MA (2007) Restoring streams in an urbanizing world. Freshw Biol 52:738-751

Bovee KD (1986) Development and evaluation of habitat suitability criteria for use in the instream flow incremental methodology. Fort Collins, CO, U.S. Fish and Wildl Serv Biol Rep 86(7)

Bovee KD, Milhous RT (1978) Hydraulic simulation in instream flow studies: theory and technique. Instream Flow Paper No. 5, U. S. Fish and Wildlife Service/Office of Biological Services-78/33
Cabral MJ, Almeida J, Almeida PR, Dellinger T, Ferrand de Almeida N, Oliveira ME, Palmeirim JM, Queiroz AL, Rogado L, Santos-Reis M (2006) Livro Vermelho dos Vertebrados de Portugal. Instituto da Conservação da Natureza, Assírio \& Alvim, Lisbon

Capra H, Breil P, Souchon Y (1995) A new tool to interpret magnitude and duration of fish habitat variations. Regul Rivers 10:281-289

Cole RA, Johnston HT, Robinson DJ (2003) The use of flow duration curves as a data quality tool. Hydrolog Sci J 48:939-951

Copp GH (1989) The habitat diversity and fish reproductive function of floodplain ecosystems. Environ Biol Fish 26:1-27

Copp GH, Jurajda P (1999) Size-structured diel use of river banks by fish. Aquat Sci 61:75-91

Copp GH, Vilizzi L (2004) Spatial and ontogenetic variability in the microhabitat use of stream-dwelling spined loach (Cobitis taenia) and stone loach (Barbatula barbatula). J Appl Ichthyol 20:440-451

Cowx IG, Welcomme RL (1998) Rehabilitation of rivers for fish. Fishing News Books, Blackwell Science, Oxford

Crowder DW, Diplas P (2000) Using two-dimensional hydrodynamic models at scales of ecological importance. J Hydrol 230:172-191

Downs PW, Kondolf GM (2002) Post-project appraisals in adaptive management of river channel restoration. Environ Manag 29:477-496

Dudgeon D, Arthington AH, Gessner MO, Kawabata ZI, Knowler DJ, Lévêque C, Naiman RJ, Prieur-Richard AH, Soto D, Stiassny ML, Sullivan CA (2006) Freshwater biodiversity: importance, threats, status and conservation challenges. Biol Rev 81:163-182

EC (2000) Council Directive for a legislative frame and actions for the water policy. 2000/60/EC, Official Journal of the EC 22/12/2000

Garcia de Jalón D, Gortázar J (2007) Evaluation of instream habitat enhancement options using fish habitat simulations: case-studies in the river pas (Spain). Aquat Ecol 41:461-474

Gasith A, Resh VH (1999) Streams in mediterranean climate regions: abiotic influences and biotic responses to predictable seasonal events. Annu Rev Ecol Syst 30:51-81

Ghanem A, Steffler P, Hicks F (1996) Two dimensional hydraulic simulation of physical habitat conditions in flowing streams. Regul Rivers 12:185-200

Gorman OT, Karr JR (1978) Habitat structure and stream fish communities. Ecology 59:507-515

Jansson R, Nilsson C, Malqvist B (2007) Restoring freshwater ecosystems in riverine landscapes: the roles of connectivity and recovery processes. Freshwater Biol 52:589-596

Jenkins M (2003) Prospects for biodiversity. Science 302:1175-1177

Lacey RW, Millar RG (2004) Reach scale hydraulic assessment of instream salmonid habitat restoration. J Am Water Res Assoc 40:1631-1644

Langler GJ, Smith C (2001) Effects of habitat enhancement on 0group fishes in a lowland river. Regul Rivers 17:677-686

Nilsson C, Jansson R, Malqvist B, Naiman RJ (2007) Restoring riverine landscapes: the challenge of identifying priorities, reference states, and techniques. Ecol Soc 12(1):16 
Palmer MA, Bernhardt ES, Allan JD, Lake PS, Alexander G, Brooks S, Carr J, Clayton S, Dahm CN, Follstad Shah J, Galat DL, Loss SG, Goodwin P, Hart DD, Hassett B, Jenkinson R, Kondolf GM, Lave R, Meyer JL, O'Donnell TK, Pagano L, Sudduth E (2005) Standards for ecologically successful river restoration. J Appl Ecol 42:208-217

Pasternack GB, Wang CL, Merz JE (2004) Application of a 2D hydrodynamic model to design of reach-scale spawning gravel replenishment on the mokelumne river, California. River Res Appl 20:205-225

Pires AM, Da Costa LM, Alves MJ, Coelho MM (2004) Fish assemblage structure across the Arade basin (southern Portugal). Cybium 28:357-365

Pretty JL, Harrison SC, Shepherd DJ, Smith C, Hildrew AG, Hey RD (2003) River rehabilitation and fish populations: assessing the benefit of instream structures. J Appl Ecol 40:251-265

Roni P, Beechie TJ, Bilby RE, Leonetti FE, Pollock MM, Pess GR (2002) A review of stream restoration techniques and a hierarchical strategy for prioritizing restoration in pacific northwest watersheds. N Am J Fish Manag 22:1-20

Roni P, Hanson K, Beechie T, Pess G, Pollock M, Bartley DM (2005) Habitat rehabilitation for inland fisheries. Global review of effectiveness and guidance for rehabilitation of freshwater ecosystems. FAO Fisheries Technical Paper. No. 484. Rome, FAO. 116p

Santos JM, Ferreira MT (2008) Microhabitat use by endangered Iberian cyprinids nase Iberochondrostoma almacai and chub Squalius aradensis. Aquat Sci 70:272-281

Schiemer F, Spindler T, Wintersberger H, Schneider A, Chovanec A (1991) Fish fry: important indicators for the ecological status of large rivers. Int Ver The 24:2497-2500
Schlosser IJ (1995) Critical landscape attributes that influence fish population dynamics in headwater streams. Hydrobiologia 303:71-81

Smith A, Katopodis C, Steffler P (2002) Assessment of flow characteristics of fish habitat structures in a constructed tundra channel using the River2D finite element model. In: Proceedings of 4th ecohydraulics symposium and conference on environmental flows for river systems. Cape Town, South Africa

Steffler P (2000) Software River2D. Two dimensional depth averaged finite element hydrodynamic model. University of Alberta, Canada

Swales S (1994) Habitat restoration methods—a synthesis. In: Cowx IG (ed) Rehabilitation of freshwater fisheries. Fishing New Books, Cambridge, pp 133-137

Tánago MG, Garcia de Jálon D (2007) Restauración de rios. Guía metodológica para la elaboración de proyectos. Ministerio de Medio Ambiente, España

Vehanen T, Huusko A, Yrjana T, Lathi M, Maki-Petays A (2003) Habitat preference by grayling (Thymallus thymallus) in an artificially modified, hydropeaking riverbed: a contribution to understand the effectiveness of habitat enhancement measures. J Appl Ichthyol 19:15-20

Vismara R, Azzellino A, Bosi R, Crosa G, Gentili G (2001) Habitat suitability curves for brown trout (Salmo trutta fario L.) in the river adda, Northern Italy: comparing univariate and multivariate approaches. Regul River 17:37-50

Woolsey S, Capelli F, Gonser T, Hoehn E, Hostmann M, Junker B, Paetzold A, Roulier C, Schweizer S, Tiegs SD, Tockner K, Weber C, Peter A (2007) A strategy to assess river restoration success. Freshwater Biol 52:752-769 